\title{
What Does It Take to Be a Good Lawyer? The Underpinnings of Success in a Rapidly Growing Legal Market
}

\author{
Piotr Bialowolski ${ }^{1,2, *(D)}$ and Dorota Weziak-Bialowolska ${ }^{2}$ (D) \\ 1 Department of Management, WSB University, 41-300 Dąbrowa Górnicza, Poland \\ 2 Sustainability and Health Initiative (SHINE), Department of Environmental Health, Harvard T. H. \\ Chan School of Public Health, Boston, MA 02115, USA; doweziak@hsph.harvard.edu \\ * Correspondence: pbialowolski@hsph.harvard.edu
}

check for updates

Citation: Bialowolski, P.;

Weziak-Bialowolska, D. What Does It Take to Be a Good Lawyer? The Underpinnings of Success in a Rapidly Growing Legal Market. Sustainability 2021, 13, 5841. https:// doi.org/10.3390/su13115841

Academic Editor: Benedict Sheehy

Received: 13 April 2021

Accepted: 20 May 2021

Published: 22 May 2021

Publisher's Note: MDPI stays neutral with regard to jurisdictional claims in published maps and institutional affiliations.

Copyright: (c) 2021 by the authors. Licensee MDPI, Basel, Switzerland. This article is an open access article distributed under the terms and conditions of the Creative Commons Attribution (CC BY) license (https:// creativecommons.org/licenses/by/ $4.0 /)$.
Abstract: The study identified the principal professional domains leading to success in legal professions. Based on a sample of 300 Polish attorneys, with the use of confirmatory factor analysis and 22 specific items, four principal domains of success were discerned-professional skills, marketing skills, reputation, and ethics. The evolution of these domains in Poland between 2005 and 2017 was examined, revealing that the importance of marketing skills significantly increased, while the remaining three domains lost importance over the study period. The results also indicated that legal professionals were more inclined to value professional skills, marketing skills, and ethics when their clients had an ability to measure the quality of legal service provided. The same domains transpired as important for lawyers, who attributed high importance to the role of the bar.

Keywords: legal service quality; sustainable success in legal professions; efficient service provision; structural equation modelling; market growth

\section{Introduction}

The market for legal services has been constantly growing and is expected to reach one trillion dollars in 2021 worldwide (Estimates of Statista.com, Available online: https: / / www.statista.com/statistics / 605125/size-of-the-global-legal-services-market/, accessed on 1 March 2021). This trend, despite being understudied from the scientific perspective, has been likely affecting the professional behavior and attitudes of legal professionals. Additionally, a general transformation of work environments has ensued over recent years, and numerous professions have been faced with substantial changes affecting their working conditions and altering the requirements necessary for the successful performance of their jobs [1]. Although legal professions are not usually on the frontline of the disruption caused by technology and automation, there is mounting evidence that more skilled professionals can be replaced with less skilled ones when the latter are assisted by technology [2]. Sometimes even the technology itself can take over the role of primary service provider, rendering humans obsolete. Expert systems have been already shown to outperform legal professionals in certain tasks [3]. These changes have a profound influence on the set of skills required to achieve success in a profession, and professionals are often pushed into uncharted territory [4].

Legal professionals play an important role for sustainable development of the economy and their services provide vital functions in liberal democracy [5]. Substantial body of literature assumes that lawyers operate under the premise of public interest theory [6], which, if true, leads to lower transactional costs and higher efficiency of the whole judicial system. Yet, in order to maintain high standards, it requires a certain level of regulation, which limits competition but also bars access to the professions for unskilled lawyers. However, as a lot of scientific argument suggest [7,8], if private interests of lawyers prevail, there is a risk that protection of the legal profession from an outside competition would shift 
the focus of legal professionals away from professional expertise and ethical behavior to marketing. This, in turn, may lead to a reduced efficiency and disrupt sustainable growth.

Lack of efficiency in the delivery of services is one of the key problems faced by the legal profession $[9,10]$. Markets, in general, and the market for legal services in particular, are constantly seeking equilibrium between supply and demand. Rapidly changing technology, as well as the evolving expectations of clients, require constant adjustments in attitudes and behavior from legal professionals to enable them to comply with their clients' needs. However, one should take into account the fact that the legal professions are still largely dependent on self-regulation, i.e., regulation executed by legal professionals themselves, and are overwhelmingly subject to the public interest argument for regulation, namely, that higher restrictions governing access to the profession are crucial to the security of consumers and quality of the services. These convictions have already been contested. It has been argued that, first, the entry barriers associated with self-regulation create inefficiencies which impede operations, innovation, and technological advance [11]. Second, if left without external supervision, self-regulation might lead to reduced competition and consequently to an environment conducive to professional misconduct [12]. Third, lawyers under self-regulation might put their private interest above public interest [13-15].

Poland, with its strong tradition of grass-root organizations, was an environment conducive to the idea of self-regulation and, over the years, Polish bar associations gained considerable influence over the provision of legal services [16]. In response, substantial changes aiming to deregulate and increase access to the legal professions have been implemented in Poland since 2005. For example, by lessening the very limited access to legal apprenticeships and bar exams, the restrictions on access to the legal professions of advocate and legal advisor were reduced. This deregulation took place in two steps: (1) the Law on Advocates, Legal Advisors and Notaries, introduced in 2005 (Journal of Laws No. 163, item 1361), and (2) the Law of 20 February 2009 amending the Law on Advocates, Legal Advisors, and Notaries (Journal of Laws 2009, vol. 37, item 286). The deregulating acts not only shortened the time required to complete an apprenticeship but also provided a legal basis for becoming a legal professional even without completing an apprenticeship. More importantly, legal professionals gained much more transparency on their career path. Although self-governing legal bodies maintained their high autonomy [16], a number of regulations worked in the direction of more market-oriented conditions for prospective legal professionals: bar exams were harmonized across the country, the threshold to pass the exam was reduced, and it became a rule to disclose legal documents used for constructing exam questions in advance. This deregulating trend coincided with considerable economic growth in Poland. Between 2005 and 2020, the Gross Domestic Product of Poland increased by almost $70 \%$ in real terms, which led to a considerable increase in the demand for goods and services. Services, including legal services, were particularly affected by the increase in demand.

The outcome of these changes on the functioning of legal professions is a vastly understudied issue. Therefore, this article has four aims. First, being based on an empirical study of Polish lawyers, it intends to identify the factors necessary to succeed in legal professions. Second, it aims to establish the evolution of the importance of these factors in response to the deregulating efforts by the Polish government and to the rapidly growing economy. Thus, it examines how the importance of those factors evolved in the rapidly changing market environment with (i) an increased demand for legal services fostered by the economic growth, and (ii) the growth in the supply of legal services propelled by the relaxed access to the profession. Third, as there is a constant debate whether legal services should be classified within the realm of experience or credence goods, it assesses the impact of the ability of clients to assess the quality of legal service on the perceived importance of different factors critical for success in legal professions. Fourth, it links the evolution of the importance of different factors necessary for success in legal professions to the attitude of lawyers towards their professional organizations, namely bars. 


\section{Background}

\subsection{Factors Critical for Success in Legal Professions}

Success in any profession depends on a number of factors that allow professionals to attract new customers and retain existing ones. Such factors as product, delivery, environment [17], technical quality (what a customer gets) and functional quality (how a customer gets it) [18], as well as the interaction of quality, physical environment quality and outcome quality [19], are pivotal for success in any service industry. The skills necessary to thrive in legal professions also take into account the specific characteristics of this profession and of the typical business interactions with clients. Parasuraman, Zeithaml, and Berry [20] identified the following core dimensions for service quality in legal professions: tangibles, reliability, responsiveness, assurance, and empathy. In the United Kingdom, the Legal Services Consumer Panel adjusted the approach, developing six corresponding characteristics of good quality service in legal professions: empathy, efficient processes, achieving outcomes, clarity and de-mystification, proactive use of legal knowledge, and professional presentation [21]. Both approaches emphasize that, in legal professions, apart from good client care, it is important to deliver technical competence and provide utility in the form of efficient outcomes [21,22].

While looking to achieve the best outcomes for their clients, legal practitioners should use their legal knowledge to search for solutions that best suit clients' needs, even if it is not what their clients explicitly requested them to do. Although a client may not be able to assess the expertise and technical competence of a lawyer, she is likely to evaluate the impression made by the lawyer, which is revealed in the appearance of being knowledgeable, experienced, professional, trustworthy, empathetic, moral, honest, wellmannered, courageous, determined, available when needed, communicative, efficient, effective, and even innovative [20]. These personal characteristics of a lawyer play a role in service delivery, although their importance may vary depending on the kind of legal tasks. For instance, not all lawyers need to stay in touch with their clients, especially if they work for a big law firm. For some lawyers, e.g., those dealing with legal analysis, success depends mostly on their specialization and technical competences. Some lawyers might work in an environment where clients would value more empathy and care, which is particularly likely among those working in family law, where a lawyer must help to facilitate the personal aspects of the legal procedure.

\subsection{The Impact of Difficulties in Assessment of the Quality of Legal Service-Credence Goods}

There is a natural imbalance between a legal professional and her client. It arises from the fact that the professional is expected to be more knowledgeable in the field and the client expects to gain from this knowledge asymmetry [3]. This particular character of legal services affects the factors necessary to achieve success in the profession. In contrast to many other goods and services, the quality of legal services poses a number of challenges in assessment from the perspective of a client. Beyond the core legal skills of a lawyer, diverse factors might matter for the final success of a legal professional on the market. Legal professionals provide a service that can be classified as being within the domain of credence goods. (The initial classification of consumer goods into search and experience goods [23,24] was broadened by Darby and Karni [25] with the category of credence goods.) Chaserant and Harnay [6] identified three potential issues indicating that legal services fall into this category. First, consumers cannot be certain whether they need a legal service, and they need to trust a legal professional on the issue. Second, consumers cannot provide an assessment of quality before taking on the service, as there is no service quality indicator available to establish how a lawyer might potentially handle the case. Third, even after the utilization of the service, clients remain unaware as to whether the lawyer serving them exerted sufficient effort to win the case and, most often, they cannot be certain if she had sufficient knowledge to address the issue at hand.

Quality assessment in the realm of legal services is often hindered because contact with a lawyer is very often a once-in-a-lifetime experience for their clients, e.g., in the event 
of a divorce, an accident, or a bankruptcy [6]. In addition, lawyers are often needed at times when a customer may not have time or willingness to devote a substantial amount of time to search for and select a legal professional. This can be relevant to family issues, criminal cases, damages, or other matters [26]. Due to a lack of prior experience in the matter at hand, consumers are not able to properly judge the quality of service. Additionally, legal services are very often tailored to current needs, which makes them even harder to judge and gives them even more of the characteristics of credence goods. Professionals are thus much more inclined to promote their services using pure marketing techniques, as consumers remain unaware of the quality of the service provided even after they receive it [27].

Chaserant and Harnay [6] point out that not all legal services fall into the credence good category. Some legal services can fall into the category of experience goods, and information about their quality can be learned after the service was provided. In such a case, the quality can be assessed for routine services for which consumers exhibit similar needs and can express similar valuations. These more routine services are of crucial importance because they can be more easily deregulated and the quality control over those services can be maintained. It is likely that those lawyers who perform legal services falling into that category would be more exposed to the assessment provided by their clients and thus more inclined to rely on their professional skills.

Since legal services possess the general characteristics of credence goods, there is a risk that, in a non-regulated environment, information asymmetries and externalities might lead to the issue of adverse selection. It might be expected that "good" lawyers charging high prices would be eliminated from the market and only "bad" lawyers providing low pricing would be left. The skills and competences necessary to succeed in such an environment might be different to the skills necessary to thrive in a regulated environment. As changes towards more market-oriented settings have been introduced in Poland, the skills and competences necessary to survive and to succeed are also likely to change. It is likely that skills more closely related to marketing and selling will become more important for success in legal professions as the market is deregulated, bringing with it limited external protection for the provision of legal services.

\subsection{Evolution of Market Conditions towards Lower Regulation-Public Interest vs. Private Interest Debate in Poland}

Pearce and Nasseri [5] argue that lawyers provide vital functions in a liberal democracy and thus the barriers to the entry to the profession should be set as low as reasonably possible. Broader access to legal services implies that individual rights can be better protected, and thus the rule of law can be better enforced. However, the features of legal services mentioned in Section 2.2 create a valid public interest argument to regulate their provision. Auriol and Schilizzi [28] indicate that, in the case of credence goods, certification and licensing is a necessity to maintain their optimal quality, as otherwise the "lemons" problem might surface [29]. (The "lemons" problem refers to the lack of ability of a buyer to assess the quality of a purchased good. Consequently, sellers of premium quality goods are at a disadvantage because they cannot charge a premium for the high quality they offer, while sellers of low quality goods (lemons) can charge the regular market price. One of the consequences of the "lemons" problem is that high quality sellers are pushed out of the market.) Regulation is supposed to protect the interests of clients, third parties, and others than those of legal service providers [8]. According to Love and Stephen [27] self-regulation can be responsible for producing at least three types of externalities: (1) restrictions to entry, (2) restrictions on advertising, and (3) restrictions on fee competition. That being said, it is not certain how regulation shapes the behavior of legal professionals. The evidence of (1) which competences become crucial in a regulated environment, and (2) how the importance of competences changes as the regulatory environment is relaxing and the economy is growing, is very limited.

The situation in the Polish legal market in the early 2000s seemed to have tilted the scale in the direction of the private interests of legal professionals. At least three different 
sets of factors might have been in play, enhancing the importance of private interests in legal professions [10]. First, the rapidly growing and deregulating market exacerbated the search problem, as consumers needed to identify, among competing firms and lawyers, that which was best suited for their interest. Second, the rapidly growing market impeded efficient price comparisons and comparison shopping. Third, a high uncertainty concerning the real value of legal work emerged because legal professionals often adopted contingencybased pricing. Yet, at the same time, a very low number of legal professionals was actively providing legal services.

Poland was lagging in terms of the number of active lawyers in comparison to other countries in Europe. In 2003 only 59 practicing lawyers per 100,000 inhabitants were registered in Poland. This prompted a debate for a market deregulation. Similarly to the UK, the number of Polish legal professionals rose significantly after deregulation, reaching average European level. Specifically, thanks to the deregulation and rapid economic growth, the number of active legal professionals went up more than twofold (to 137 per 100,000 inhabitants) in 2014. However, there was still a substantial potential for the growth of the legal profession. There are 391 active lawyers per 100,000 inhabitants in the United States, while in England and Wales there are 251, and in Australia there are 357. It should be understood, though, that the number of lawyers is not always determinant of the level of development. In Canada, there are only 26 lawyers per 100,000 people, and in Japan there are only 23 .

Following deregulation, the exclusive rights of advocates and legal advisors were confined to a representation in front of a court, which attracted a pool of law graduates to establish their own law firms, provide legal counsel, and draft contracts independent of advocates and legal advisors. In this respect, the deregulation consisted of de-licensing legal advice [30]. Easier and more transparent access to legal professions was brought about by curbing the omnipotent role of the bar and harmonizing nationally bar training and professional examinations.

Legal practice is often subject to self-regulation by the bar associations, which decide the number of active lawyers and monitor their competences and performance. However, the approach to legal market regulation relying on bars to provide necessary regulatory framework recently started to change raising the question about the benefits provided by self-regulation. It has been argued that bar associations strive to advance the interests of their own members, while they should focus their efforts of advancing public good, benefitting consumers, general society, and courts. Finding the right balance to protect the interests of the professional group, while at the same time providing public service, is a complex task and requires identifying all potential failures (e.g., rent-seeking, information constraints) that might affect the equilibrium of the market and, subsequently, introducing mechanisms that allow to correct for inefficiencies. Thus, in the long-run, deregulation that affects the functioning of the market in general, and its self-governing organizations (bars) in particular, can have positive effects on the economy by attracting a larger pool of legal professionals to provide services [11], but it remains unclear what skills might transpire as contributing to success on the market after the regulatory changes are introduced. Is the set of professional skills sufficient, or should the market demand other skills in order for a professional to prosper? Deregulation in Poland was market-oriented and stimulated the competition on the market. It is, however, not clear what kind of changes it prompted in the behavior of legal professionals. Even though dismantling regulations might prove beneficial for competition in the legal services sector, the problems of adverse selection (i.e., poor lawyers replacing good ones) and moral hazard (providing poor quality service is not identifiable by consumer) might become much more apparent [6] due to the changing expectations of the market with respect to the skill sets of legal professionals. This might have prompted lawyers to focus not on professional but rather on market-oriented skills in their practice. 


\subsection{Research Hypotheses}

Based on the theoretical considerations presented above, the following hypotheses were formulated:

Hypotheses 1 (H1). Following rapid economic growth and market deregulation, the market for legal services became more market-oriented, and market-related skills became more important for achieving success in legal professions.

Hypotheses 2 (H2). The importance of professional skills is higher among lawyers who serve clients who are able to identify the quality of the legal work provided ( $\mathrm{H} 2 a$ ), while reputation is more important for those lawyers whose clients are unable to identify the quality of legal work (H2b).

Hypotheses 3 (H3). Lawyers who value high professionalism and high ethical standards put more emphasis on the importance of bar associations (H3a), while those who value marketing skills do not appreciate the role of bar associations (H3b).

\section{Materials and Methods}

\subsection{Data}

A dedicated survey to assess competences of legal professionals in Poland was conducted between December 2017 and March 2018. The respondents-mostly advocates but also other legal professionals-were approached by an e-mail with a request to answer a set of questions in a short 6 min survey delivered via the SurveyMonkey platform. The survey focused on an evaluation of competences necessary for legal professionals to achieve success in the profession assessed in two specific points in time: (1) retrospectively, in 2005, that is before the period of deregulation and rapid economic growth, and (2) on the day of the survey. It was assumed that lawyers were knowledgeable about the factors necessary to achieve success in legal professions before the deregulation and at the time of the survey. Even if some of the respondents were not active lawyers in 2005, we assumed that they interacted with legal professionals who were active at the time (being either their students or trainees). Additionally, our respondents could infer about the skills necessary to achieve success before their started their legal careers from interactions with their peers. Approximately 300 respondents provided responses to the entire survey, enabling the analysis of the evolution in the factors necessary to achieve success in legal professions and the factors driving the change.

\subsection{Sample}

Advocates were in the preponderance of those sampled (96.9\%). A small number of other professionals from different fields of legal specialization also participated. The survey collected information on age, income, tenure in legal professions, area of specialization, type of principal client and size of place where legal services are delivered (Table 1). These variables also served as controls in the subsequent analyses.

Most respondents were young- $73 \%$ were below the age of 45 . In total, $44.7 \%$ of the respondents did not have more than 9 years of legal experience. As far as the legal specialization was concerned, often more than one specialization was chosen by the respondents. The largest group (86.9\%) specialized in civil law, but more than half of legal professionals also practiced business law $(59.1 \%)$, criminal law $(55.4 \%)$ and/or family law (50.7\%). In total, $69.7 \%$ of the surveyed lawyers declared an average yearly income below 100,000 PLN, and $59.1 \%$ of the respondents served individuals, while $36.2 \%$ declared to mostly work with companies. Finally, $56.8 \%$ of the respondents were from larger cities, mainly those with more than 500,000 inhabitants. 
Table 1. Sample characteristics.

\begin{tabular}{|c|c|c|}
\hline Characteristic & Response Option & $\%$ \\
\hline \multirow{4}{*}{$\begin{array}{l}\text { What is your affiliation within } \\
\text { legal professions? }(\mathrm{N}=291)\end{array}$} & Advocate & 96.9 \\
\hline & Legal advisor & 2.4 \\
\hline & Legal apprentice & 0.3 \\
\hline & Other & 0.3 \\
\hline \multirow{5}{*}{ What is your age? $(\mathrm{N}=296)$} & Up to 34 & 30.1 \\
\hline & $35-44$ & 42.9 \\
\hline & $45-54$ & 12.5 \\
\hline & $55-64$ & 9.5 \\
\hline & $65+$ & 5.1 \\
\hline \multirow{4}{*}{$\begin{array}{l}\text { What is your experience in a } \\
\text { legal profession? }(\mathrm{N}=293)\end{array}$} & Less than 5 years & 15.0 \\
\hline & 5-9 years & 29.7 \\
\hline & $10-19$ years & 33.8 \\
\hline & $20+$ years & 21.5 \\
\hline \multirow{9}{*}{$\begin{array}{c}\text { What is your legal } \\
\text { specialization? }(\mathrm{N}=296)\end{array}$} & Civil law & 86.8 \\
\hline & Family law & 50.7 \\
\hline & Criminal law & 55.4 \\
\hline & Administrative law & 18.2 \\
\hline & Business law & 59.1 \\
\hline & Tax law & 6.1 \\
\hline & Labor law & 21.3 \\
\hline & Social security law & 10.8 \\
\hline & Other & 23.7 \\
\hline \multirow{5}{*}{$\begin{array}{l}\text { What is your average yearly } \\
\text { income in PLN }(1 \text { PLN } \approx 0.26 \\
\text { USD)? }(\mathrm{N}=274)\end{array}$} & Less than 30,000 PLN & 26.3 \\
\hline & 30,000-49,999 PLN & 17.5 \\
\hline & 50,000-99,999 PLN & 25.9 \\
\hline & $100,000-299,999$ PLN & 21.5 \\
\hline & 300,000+ PLN & 8.8 \\
\hline \multirow{4}{*}{$\begin{array}{l}\text { Who is your principal } \\
\text { customer? }(N=296)\end{array}$} & Individuals & 59.1 \\
\hline & Companies & 36.2 \\
\hline & My employer & 2.0 \\
\hline & Other & 2.7 \\
\hline \multirow{2}{*}{$\begin{array}{c}\text { Size of the metropolitan area } \\
\text { in which respondent provides } \\
\text { legal services }(\mathrm{N}=296)\end{array}$} & City over 500,000 inhabitants & 56.8 \\
\hline & $\begin{array}{c}\text { City up to } 500,000 \text { inhabitants, } \\
\text { town or village }\end{array}$ & 43.2 \\
\hline
\end{tabular}

\subsection{Outcomes}

Respondents were requested to assess the importance of various elements for success in legal professions. Twenty-two aspects of the conduct of a legal professional as well as the environment in which the legal service was delivered were examined. Examples of the elements included legal knowledge, efficiency, patronage, education, marketing, personal skills, and ethics. The importance was measured on a 7-point scale, where 1 represented an element completely irrelevant for the success in legal professions and 7 represented an element extremely relevant for success in legal professions. The full list of the examined elements is presented in Table 3.

\subsection{Salient Covariates}

Two questions from the survey were used to explain the importance of different dimensions identified as critical for success in legal professions. Respondents elaborated on the ability of their customers to assess the quality of their legal work (for detailed wording, see Table 2). Even though the largest group of legal service customers (42.6\%) had some idea about the quality of legal work provided, a considerable group of customers $(31.9 \%)$ was either completely unaware of the quality of legal service or would have had difficulties in providing an assessment of the quality. As we argued, legal services are at the 
verge of experience goods and credence goods, thus the set of skills emerging as important might be different for lawyers who provide services closer to experience goods than for those who provide services in the realm of credence goods.

Table 2. Salient covariates (question, response scale and response rates).

\begin{tabular}{|c|c|c|}
\hline Question & Response Scale & $\%$ \\
\hline \multirow{4}{*}{$\begin{array}{l}\text { To what extent are your clients (or your } \\
\text { employer) able to identify (assess) the } \\
\text { quality of your work? ( } \mathrm{N}=291 \text { ) }\end{array}$} & They easily identify when work is done reliably and when not & 25.4 \\
\hline & They have a certain idea when the work is done well and when it is not & 42.6 \\
\hline & $\begin{array}{l}\text { It is difficult for them to determine when a job is done well and } \\
\text { when it is not }\end{array}$ & 27.8 \\
\hline & $\begin{array}{l}\text { They are not able to determine when the work is done well and } \\
\text { when it is not }\end{array}$ & 4.1 \\
\hline \multirow{4}{*}{$\begin{array}{l}\text { To what extent is the form of organization } \\
\text { of legal professions (application, exam, } \\
\text { bar and disciplinary liability) a guarantee } \\
\text { of proper customer service? ( } \mathrm{N}=299 \text { ) }\end{array}$} & It does not help at all & 10.4 \\
\hline & Helps to a small extent & 33.8 \\
\hline & It helps satisfactorily & 37.1 \\
\hline & Guarantees very well & 18.7 \\
\hline
\end{tabular}

The second question concerned the importance of bar associations (see Table 2 for the exact wording). Their role has been significantly affected over the period of interest, and they are pivotal in striving between the private and the public interest theories for regulation of legal professions (see Section 2.3). It is important to examine whether lawyers who perceive them as pivotal for the profession emphasize skills of legal professionals different than those emphasized by lawyers who do not attach a significant role to the presence of bar associations. A majority of lawyers participating in the survey (55.8\%) replied that bar associations either help to satisfactorily provide, or to effectively ensure the provision of, proper customer service. However, $10.4 \%$ claimed that bar associations do not help at all in guaranteeing the proper level of service.

\subsection{Statistical Analyses}

A set of 22 indicators was used to identify professional domains related to success in legal professions. The set comprised a detailed list of items covering the fields identified as critical for the quality of services in general and in particular for the quality of legal services. Descriptive statistics were first computed to determine the average importance of factors necessary to achieve success in legal professions in Poland before and after the period of deregulation and rapid economic growth. Second, these factors were grouped into professional domains. To this end, a dimensionality analysis was conducted using an initially proposed set of indicators and exploratory factor analysis. The aim was to identify broad professional domains that are relevant to the success in legal professions. Significant estimates of the geomin rotated factor loadings in the exploratory factor analysis were used to specify a confirmatory factor model, which was subsequently tested for intertemporal consistency. Next, a series of tests for measurement invariance was conducted with confirmatory factor analysis models. Model comparisons in the multiple-group factor analysis framework were estimated to ensure that the factorial structure was robust in relation to time. We evaluated the fit of the multi-group configural, metric and scalar models using the fit statistics (see, e.g., for a detailed description of the approach [31]).

Exploratory and confirmatory factor analyses have been applied in various fields and aim to determine the number and nature of factors that account for the variation in the set of indicators [32,33]. To put it differently, the set of indicators is correlated because there is an underlying cause (or causes) behind it, which in our case corresponds to the importance of a specific professional domain. In this study, factor analysis was applied to determine the number of factors (i.e., latent variables corresponding to professional domains) that are reflected in the set of indicators responsible for professional success. The number of factors that are responsible for the performance of lawyers was established based on the Bayesian information criterion (BIC), which is a measure of model performance [34]. Lower BIC 
means that a model is considered to be more likely to be the true model. When comparing different models, the rule is to choose the model with the lowest BIC. Additionally, a set of commonly accepted measures of fit, which are used to accept the model derived from the factor analytical framework, was also used. They comprise Root Mean Square Error of Approximation (RMSEA), Comparative Fit Index (CFI) and Tucker-Lewis Index (TLI). With respect to RMSEA, the commonly accepted values should be within the range of 0.00-0.05 [35]. With respect to CFI and TLI, it is usually assumed that to judge the model as well-fitted, these statistics should be above 0.95 [36]. We required that the fit statistics for the selected models lie within those ranges to accept the models for further analysis. Detailed results are available upon request from the corresponding author.

Having established the measurement invariance of the factorial structure, the changes in the importance of factors responsible for the success in the legal professions in Poland contemporaneously and before 2006 were examined. In the final step, a structural equation model was estimated to simultaneously analyze the impact of the socio-economic characteristics of legal professionals, their professional specialization, their positioning regarding the importance of bar associations, and the identifiability of the quality of their work outcomes for their customers on the importance of different dimensions for success achievement. Structural equation modelling allows to add covariates to confirmatory factor analysis model and identify variables that significantly influence latent variables (i.e., the importance of specific domains responsible for professional success in legal professions in our case). Specifically, the identified dimensions of professional success were regressed on the set of covariates and controls. All variables were recoded into dichotomous ones. The model was estimated simultaneously for all the dimensions of legal success.

\section{Results}

\subsection{Importance}

Highly diverse results were obtained for the importance of specific factors for success in legal professions for the periods before 2006 and 2017/2018 (the date of the survey) (see Table 3). We found that the average importance of legal profession attributes increased by almost 0.5 points on a 1-7 scale, pointing to a change towards a more competitive legal environment over the period of 12 years. However, the change was not unidimensional. Out of 22 attributes important for the success in legal professions, the importance of 13 features went up (in 11 cases the change was statistically significant) and the importance of nine features decreased (in seven cases, the change was statistically significant).

Among the features whose importance increased the most were: selling skills (an increase by almost 3 points on a 7-point scale), innovativeness (an increase by 2.3 points), pugnacity (an increase by 2.1 points), and specialization (an increase by 2.0 points). The substantial increase in the importance of selling skills constituted a primary confirmation of H1. The importance of continued education and specialization were also indicated by the participants as a source of success in the contemporary legal environment. Instead, among the features whose importance decreased the most, we observed patron renown (a decrease by 1.6 points), ethics of conduct (a decrease by 1.4 points), reputation of the alma mater (a decrease by 1.3 points) and propriety (a decrease by 1.1 points). 
Table 3. Average importance of factors necessary to achieve success in legal professions in Poland-before 2006 and in 2017/2018 (1-completely irrelevant for the success in legal professions, 7-extremely relevant for the success in legal professions; ranked according to the change in importance).

\begin{tabular}{ccccc}
\hline Element of Success & Importance before 2006 & Importance in 2017/2018 & Change in Importance & Significance \\
\hline Selling skills & 3.31 & 6.29 & 2.98 & 2.30 \\
Innovativeness & 3.09 & 5.39 & 2.06 & 0.000 \\
Pugnacity & 3.96 & 6.02 & 2.04 & 0.000 \\
Specialization & 3.51 & 5.55 & 1.99 & 0.000 \\
Flexibility & 3.90 & 5.89 & 1.52 & 0.000 \\
Access to customer base & 4.64 & 6.41 & 1.18 & 0.000 \\
Artifice & 4.35 & 5.87 & 1.02 & 0.000 \\
Work for an established & 4.16 & 5.34 & 0.78 & 0.000 \\
legal firm & 4.45 & 5.47 & 0.55 & 0.15 \\
Well-organized office & 4.43 & 5.21 & 0.09 & 0.000 \\
Continued education & 5.1 & 5.65 & -0.13 & 0.000 \\
Efficiency & 5.19 & 5.34 & -0.25 & 0.325 \\
Contacts & 4.78 & 4.87 & -0.31 & 0.551 \\
Process activity & 5.12 & 4.99 & -0.66 & 0.441 \\
Accuracy & 5.33 & 5.08 & -0.85 & 0.104 \\
Legal knowledge & 5.44 & 5.13 & -1.07 & 0.045 \\
Professionalism & 5.85 & 5.19 & -1.25 & 0.000 \\
Known name & 5.11 & 4.26 & -1.42 & 0.000 \\
Honesty & 5.45 & 4.38 & -1.61 & 0.000 \\
Propriety & 4.33 & 3.08 & 3.62 & 0.000 \\
Reputation of the alma & 5.04 & 3.9 & & 0.000 \\
mater & 5.51 & & 0.000 \\
Ethics of conduct & & & & \\
Patron renown & & & & \\
\hline
\end{tabular}

4.2. Professional Domains Leading to Success in Legal Professions-Identification and Temporal Evolution

Models probing the different number of dimensions responsible for the success in legal professions were estimated with the number of latent dimensions ranging from one to six. Table 4 presents the values of Bayesian Information Criterion.

Table 4. Model fit statistics for Exploratory Factor Analysis models with number of factors ranging between 1 and 6 .

\begin{tabular}{ccccc}
\hline Model & BIC & CFI & TLI & RMSEA \\
\hline 1 factor & 22749.479 & 0.664 & 0.628 & 0.105 \\
2 factors & 22345.109 & 0.885 & 0.858 & 0.065 \\
3 factors & 22288.909 & 0.928 & 0.981 & 0.054 \\
4 factors & $\underline{22227.062}$ & $\underline{0.974}$ & $\underline{0.960}$ & $\underline{0.035}$ \\
\hline f factors & 22233.377 & 0.984 & 0.972 & 0.029 \\
6 factors & 22238.115 & 0.995 & 0.990 & 0.018 \\
\hline
\end{tabular}

Models with one and two dimensions turned out to be unsatisfactory with respect to the commonly applied measures of fit used in the factor analytical approach and structural equation modeling framework. The three-factor model was associated with merely acceptable fit statistics and only for four-factor solution were the fit-statistics found to be within the ranges suggested by the literature and, additionally, for the four-factor solution the observed value of the BIC statistics was at the lowest level-favoring this solution. The results of the four-factor solution are presented in Table 5 . 
Table 5. Unstandardized factor loadings in the confirmatory factor framework-four-factor solution.

\begin{tabular}{|c|c|c|c|c|}
\hline Element of Success & $\begin{array}{c}\text { Factor 1 } \\
\text { Professional Skills }\end{array}$ & $\begin{array}{c}\text { Factor } 2 \\
\text { Marketing Skills }\end{array}$ & $\begin{array}{c}\text { Factor } 3 \\
\text { Reputation }\end{array}$ & $\begin{array}{l}\text { Factor } 4 \\
\text { Ethics }\end{array}$ \\
\hline Legal knowledge & $1.036^{* * *}$ & & & \\
\hline Professionalism & $1 * * *$ & & & \\
\hline Accuracy & $0.962 * * *$ & & $-0.281^{* *}$ & \\
\hline Continued education & $0.706^{* * *}$ & $0.339 * * *$ & & \\
\hline Process activity & $0.701^{* * *}$ & & & \\
\hline Efficiency & $0.417^{* * *}$ & $0.263^{* * *}$ & & \\
\hline Selling skills & $-0.483^{* * *}$ & $1^{* * *}$ & & \\
\hline Innovativeness & & $0.764^{* * *}$ & & \\
\hline Flexibility & & $0.734^{* * *}$ & & \\
\hline Specialization & & $0.676^{* * *}$ & & 0.069 \\
\hline Pugnacity & & $0.656^{* * *}$ & & $-0.219^{* * *}$ \\
\hline Access to customer base & & $0.539 * * *$ & & $-0.182 * * *$ \\
\hline Well-organized office & $0.376^{* * *}$ & $0.368^{* * *}$ & & \\
\hline Contacts & & & $1.033^{* * *}$ & $-0.236^{* *}$ \\
\hline Known name & & & $1 * * *$ & 0.047 \\
\hline Patron renown & $0.815^{* * *}$ & $-0.402^{* * *}$ & $0.836^{* * *}$ & \\
\hline Reputation of the alma mater & & & $0.615^{* * *}$ & $0.563^{* * *}$ \\
\hline Artifice & & $0.475^{* * *}$ & $0.541^{* * *}$ & $-0.281^{* * *}$ \\
\hline Work for an established legal firm & & & $0.530^{* * *}$ & \\
\hline Ethics of conduct & 0.214 & & & $1 * * *$ \\
\hline Honesty & $0.504^{* * *}$ & & & $0.709^{* * *}$ \\
\hline Propriety & $0.519^{* * *}$ & & & $0.524^{* * *}$ \\
\hline $\begin{array}{l}\text { Change in in the average score in the } \\
\text { dimension (score before } 2006=0 \text { ) }\end{array}$ & $-0.313^{* * *}$ & $2.675^{* * *}$ & $-0.304 *$ & $-1.465^{* * *}$ \\
\hline Descriptive fit statistics & $\begin{array}{c}\text { CFI } \\
0.914\end{array}$ & $\begin{array}{c}\text { TLI } \\
0.906\end{array}$ & $\begin{array}{c}\text { RMSEA } \\
0.054\end{array}$ & \\
\hline
\end{tabular}

Note: ${ }^{*}$ significant at 0.1 level, ${ }^{* *}$ significant at 0.05 level, ${ }^{* * *}$ significant at 0.01 level; only significant factor loadings are reported.

The results revealed a four-dimensional structure of the broad dimensions responsible for success in legal professions. The four factors can be associated with professional skills (Factor 1), marketing skills (Factor 2), reputation (Factor 3), and ethics (Factor 4). For both professional skills and marketing skills, 11 indicators significantly reflected in each of these dimensions were identified. Professional skills were very much reflected in legal knowledge, professionalism, and continued education. They were also associated with patron renown, which can be perceived in this case as the source of legal knowledge. Professional skills were negatively related to selling skills. It might be related to the fact that selling is a time-consuming activity, and the perception that the development of better selling skills might be at odds with the development of professional skills. Marketing skills were positively associated with innovativeness, specialization, pugnacity, and access to customer base. Marketing knowledge and continued education also played a role in the marketing skills dimension. The third dimension for the success in legal professions relates to reputation. Reputation was mostly driven by the presence of a renowned patron and an extensive set of contacts. It was further supported by the value given to the prestige of the family name, the importance of which is well-known in the legal world in Poland. Reputation was also, to a degree, built on artifice, which also contributes to the dimension of marketing skills. The fourth and final dimension was classified as ethics. Apart from the ethical conduct, the virtues of honesty and propriety were associated with this dimension, along with the reputation of the alma mater. Some personal traits, including pugnacity and artifice, were negative contributions to the ethical dimension of legal professionals.

The results show that there was a significant decrease in the importance of ethics, professional skills, and reputation for Polish legal professionals over recent years (Table 5; Change in the average score in the dimension (score before $2006=0$ )). The largest decrease in importance was found for the role of ethics (1.465 points on the scale from 1 to 7 ). 
The decline in the importance of professional skills and reputation was of comparable magnitude ( 0.313 and 0.304 , respectively, measured on the 1 to 7 scale). In contrast, a large increase in the importance of marketing skills was observed over the period of analysis (an increase by 2.675 points on 1-7 scale), which constitutes a strong confirmation of H1.

\subsection{Factors Related to Success in the Legal Professions}

A structural equation modeling was applied to regress four factors (i.e., latent variable corresponding to professional skills (Factor 1), marketing skills (Factor 2), reputation (Factor 3) and ethics (Factor 4)) on a set of covariates controlling for age, experience in legal professions, income, type of client, size of the metropolitan area in which respondent provides legal services, and specialization) (Table 6).

Table 6. Determinants of skill importance-estimates of the structural equation modeling.

\begin{tabular}{|c|c|c|c|c|}
\hline \multirow[b]{2}{*}{ Covariates and Controls } & \multicolumn{4}{|c|}{ Outcomes } \\
\hline & $\begin{array}{c}\text { Factor } 1 \\
\text { Professional Skills }\end{array}$ & $\begin{array}{l}\text { Factor } 2 \\
\text { Marketing Skills }\end{array}$ & $\begin{array}{l}\text { Factor } 3 \\
\text { Reputation }\end{array}$ & $\begin{array}{c}\text { Factor } 4 \\
\text { Ethics }\end{array}$ \\
\hline \multicolumn{5}{|l|}{ Covariates } \\
\hline$\overline{\text { Clients able to easily identify quality of work }}$ & $0.326 * *$ & $0.313 *$ & 0.172 & $0.272 *$ \\
\hline $\begin{array}{l}\text { The bar (but also exams) helps to maintain high quality } \\
\text { of legal service }\end{array}$ & $0.427 * * *$ & $0.258 *$ & -0.174 & $0.547^{* * *}$ \\
\hline \multicolumn{5}{|l|}{ Controls } \\
\hline \multicolumn{5}{|l|}{$\overline{\text { Age (ref. }}=$ below 44$)$} \\
\hline $44+$ & $0.516 * * *$ & $0.696^{* * *}$ & $-0.584^{* *}$ & $0.356 *$ \\
\hline \multicolumn{5}{|l|}{ Experience in legal professions (ref. = less than 10 years) } \\
\hline At least 10 years of experience & 0.148 & -0.046 & 0.083 & 0.222 \\
\hline \multicolumn{5}{|l|}{ Yearly income (ref. = less than PLN 100,000) } \\
\hline At least PLN 100,000 & 0.134 & 0.056 & 0.002 & 0.116 \\
\hline \multicolumn{5}{|l|}{ Type of client (ref. = company or my employer) } \\
\hline Individual clients & 0.097 & -0.032 & -0.092 & 0.065 \\
\hline \multicolumn{5}{|l|}{$\begin{array}{l}\text { Size of the metropolitan area in which respondent } \\
\text { provides legal services (ref.= city up to } 500,000 \\
\text { inhabitants, town or village) }\end{array}$} \\
\hline a large city & -0.178 & -0.191 & 0.059 & 0.008 \\
\hline \multicolumn{5}{|l|}{ Specialization (ref. = no specialization.) } \\
\hline Civil law & -0.118 & 0.159 & 0.092 & -0.092 \\
\hline Family law & 0.239 & 0.073 & -0.047 & $0.298^{*}$ \\
\hline Criminal law & 0.120 & 0.006 & 0.238 & 0.174 \\
\hline Administrative law & -0.125 & 0.033 & 0.341 & 0.107 \\
\hline Business law & 0.114 & -0.112 & -0.213 & 0.068 \\
\hline Tax law & 0.136 & 0.166 & -0.347 & -0.273 \\
\hline Labor law & 0.216 & 0.209 & 0.291 & 0.164 \\
\hline Social security law & -0.144 & -0.013 & -0.050 & -0.077 \\
\hline Other & 0.252 & 0.002 & -0.225 & 0.127 \\
\hline
\end{tabular}

Note: * significant at 0.1 level, ** significant at 0.05 level, *** significant at 0.01 level; responses to the question "To what extent are your clients (or your employer) able to identify (assess) the quality of your work?" were dichotomized. When they responded, "They easily identify when work is done reliably and when not" or "They have a certain idea when the work is done well and when it is not" the response was coded as 1, and when they responded, "It is difficult for them to determine when a job is done well and when it is not" or "They are not able to determine when the work is done well and when it is not" it was coded as zero. Responses to the question "To what extent is the form of organization of legal professions (application, exam, bar and disciplinary liability) a guarantee of proper customer service?" followed the same logic. When they responded, "Guarantees very well" or, "It helps satisfactorily" the response was coded as 1 , and when they responded, "Helps to a small extent" or "It does not help at all" it was coded as zero.

We found that those lawyers who claim that their clients were able to easily identify the quality of their work emphasized the importance of professional skills, marketing skills and ethics more than those who served clients that were unable to assess quality of their work (Table 6). This corroborates hypothesis H2a, which assumes that professional 
skills would be of a particular importance for the group of lawyers providing services of measurable quality. Additionally, there was no association between the ability of clients to assess the quality of legal work and reputation. This finding provided evidence against hypothesis $\mathrm{H} 2 \mathrm{~b}$, which posits that those clients who find it difficult to assess the quality of legal work would be more likely to rely on reputation.

Our results, presented in Table 6, also indicated that the perception of the importance of bar associations is associated with the evaluation of importance of professional skills, marketing skills and ethics. This provides some support for H3a. However, despite the hypothesized association, there was no indication that those lawyers who were less appreciative of bar associations would place more emphasis on marketing skills. This implies that no support was found for $\mathrm{H} 3 \mathrm{~b}$.

\section{Discussion}

The aim of the study was to identify the key professional domains leading to success in legal professions. Among 22 indicators related to the professional quality, four principal dimensions were identified. They comprised professional skills, marketing skills, reputation and ethics. The second objective was to track the evolution of those key professional domains in Poland over a period of more than 12 years, during which a considerable growth of the market for legal services and substantial deregulation of the rules of entry to the market were observed.

We found a significant shift in the importance of the main professional domains responsible for success in the legal professions in Poland. We showed that aggregate measures related to professional skills, ethics, and reputation lost importance during the transition period of the Polish economy. However, fast market growth and deregulation were promoting, in particular, the market skills among legal professionals. Changes observed in the market for legal services in Poland show that it might have been the personal interaction that gained preeminence in the importance of legal professional skills, which is in line with the argument that in modern market economies, personal interaction is a primary determinant of a customer's overall satisfaction [37]. Our findings suggest that the increased importance of a skill, such as pugnacity, is an indicator of systemic change and the abandonment of the rules that are characteristic of the hitherto centrally planned economy. Mrowczynski [16] notes that, during socialist times, such behavior would not have been acceptable and, "If an advocate displayed too much independence or adversarial zeal when defending a client, an investigation into his or her income sources could be launched by the Prosecutor's Office or by the police." The declining importance of professionalism might suggest insufficient pressure and, more importantly, an insufficient check on quality. It is clearly visible in our results that those professionals who claim that their performance is easily measurable by their clients also tend to assign much higher value to the importance of professionalism. With a decline in other factors, especially that of professionalism, there is a risk that reduced regulation might lead to the oversupply of low-quality services, while failing to provide sufficient high-quality services and efficient legal processes at the macro level [6]. Even though our study and earlier studies on the Polish market did not confirm this effect [38], a significant tilt in the importance of market-oriented skills is undeniable. This increased importance of marketing skills should be closely monitored, as marketing is believed to have a potentially damaging impact on consumers' perceptions of social norms [39] and thus can lead to lawyers not serving the society but to serving merely their own private interests.

Despite significant deregulatory efforts in recent years in Poland, the article provides evidence for an important role of bar associations. Earlier studies showed that legal services, if well regulated, can generate positive social outcomes associated with judicial efficiency and the production of public goods such as rule of law, trust, and justice [5]. Bar associations, probably due to the stability of the environment that they provide and the accountability of lawyers that they enforce, were shown to positively influence the importance of professional skills and ethics for not only the prospects for success in legal professions but also for sustainable professional development. This might be in line with 
the conclusion of Pagliero [40], who noted that restrictions to access can generate a positive externality related to stability.

The reforms in Poland were probably indispensable, and their character probably fits into the general European trend to deregulate professions [41]. In their recent article, Białowolski and Masior [38] show that deregulation in Poland, especially in the context of growing demand, did not result in a deterioration in the quality of service, while at the same time it contributed to broadened access to legal professionals. However, the argument provided by the present study suggests that complete deregulation of legal professions might also not be the best course of action for the sustainable development of the economy and for the quality of services provided. Regulatory bodies (bars) exert pressure on the quality of service, and lawyers with a high appreciation of the role of bars seem to perceive professionalism and ethics as much more important than other factors for success in legal professions.

Author Contributions: Conceptualization, P.B.; methodology, P.B.; formal analysis, P.B.; investigation, P.B.; data curation, P.B.; writing—original draft preparation, P.B. and D.W.-B.; writing—review and editing, P.B. and D.W.-B. Both authors have read and agreed to the published version of the manuscript.

Funding: This research was funded by project funded under the program of the Ministry of Science and Higher Education (Poland) titled "Regional Initiative of Excellence" in 2019-2022, project number 018/RID/2018/19.

Institutional Review Board Statement: Ethical review and approval were waived for this minimal risk study.

Informed Consent Statement: Informed consent was obtained from all subjects involved in the study.

Data Availability Statement: The data are available for replication at https://doi.org/10.7910/ DVN/PO4KUP, accessed on 1 March 2021.

Acknowledgments: Authors would like to thank Michał Masior for his contribution to the development of the survey questionnaire.

Conflicts of Interest: The authors declare no conflict of interest. The funders had no role in the design of the study; in the collection, analyses, or interpretation of data; in the writing of the manuscript, or in the decision to publish the results.

\section{References}

1. Noordegraaf, M. Reconfiguring Professional Work: Changing Forms of Professionalism in Public Services. Adm. Soc. 2016, 48, 783-810. [CrossRef]

2. Sampson, S.E. Professional Service Jobs: Highly Paid but Subject to Disruption? Serv. Sci. 2018, 10, 457-475. [CrossRef]

3. Susskind, R.; Susskind, D. The Future of the Professions: How Technology Will Transform the Work of Human Experts; Oxford University Press: New York, NY, USA, 2015; ISBN 9780198713395.

4. Leicht, K.T.; Fennell, M.L. Institutionalism and the Professions. In The SAGE Handbook of Organizational Institutionalism; Greenwood, R., Oliver, C., Suddaby, R., Sahlin, K., Eds.; SAGE: London, UK, 2008; ISBN 9781412931236.

5. Pearce, R.G.; Nasseri, S. The virtue of low barriers to becoming a lawyer: Promoting liberal and democratic values. Int. J. Leg. Prof. 2012, 19, 357-378. [CrossRef]

6. Chaserant, C.; Harnay, S. The regulation of quality in the market for legal services: Taking the heterogeneity of legal services seriously. Eur. J. Comp. Econ. 2013, 10, 267-291.

7. Pagliero, M. What is the objective of professional licensing? Evidence from the US market for lawyers. Int. J. Ind. Organ. 2011, 29, 473-483. [CrossRef]

8. Pearce, R.G.; Semple, N.; Knake, R.N. A Taxonomy of Lawyer Regulation: How Contrasting Theories of Regulation Explain the Divergent Regulatory Regimes in Australia, England/Wales, and North America. Leg. Ethics 2014, 16, 258.

9. Knake, R.N. Democratizing the Delivery of Legal Services. Ohio State Law J. 2012. [CrossRef]

10. Semple, N. Mystery shopping: Demand-side phenomena in markets for personal plight legal services. Int. J. Leg. Prof. 2019, 26, 181-216. [CrossRef]

11. Winston, C.; Karpilow, Q. Should the US Eliminate Entry Barriers to the Practice of Law? Perspectives Shaped by Industry Deregulation. Am. Econ. Rev. Pap. Proc. 2016, 106, 171-176. [CrossRef]

12. Adams, T.L. Self-regulating professions: Past, present, future. J. Prof. Organ. 2017, 4, 70-87. [CrossRef] 
13. den Hertog, J. Economic theories of regulation. In Regulation and Economics; van den Bergh, R., Pacces, A., Eds.; Edward Elgar Publishing: Cheltenham, UK; Northampton, MA, USA, 2012; pp. 25-96.

14. Larson, M.S. The Rise of Professionalism: A Sociological Analysis; University of California Press: Berkeley, CA, USA, 1977.

15. Stigler, G.J. The Theory of Economic Regulation. Bell J. Econ. Manag. Sci. 1971, 2, 3-21. [CrossRef]

16. Mrowczynski, R. Institutional professionalization of lawyers in state-socialism and post-socialism: Poland and Russia compared. Int. J. Leg. Prof. 2016, 23, 157-184. [CrossRef]

17. Rust, R.T.; Oliver, R.L. Service Quality: Insights and Managerial Implications from the Frontier. In Service Quality: New Directions in Theory and Practice; Rust, R.T., Oliver, R.L., Eds.; SAGE Publications: Thousand Oaks, CA, USA, 1994; pp. 1-20.

18. Grönroos, C. A Service Quality Model and its Marketing Implications. Eur. J. Mark. 1984, 18, 36-44. [CrossRef]

19. Brady, M.K.; Cronin, J.J. Some new thoughts on conceptualizing perceived service quality: A hierarchical approach. J. Mark. 2001, 65, 34-49. [CrossRef]

20. Parasuraman, A.; Zeithaml, V.A.; Berry, L.L. SERVQUAL Multiple-item Measuring Perceptions of Service Quality. J. Retail. 1988, $64,12$.

21. Vanilla Research for the Legal Services Consumer Panel. Legal Services Consumer Panel Quality in Legal Services; Legal Services Consumer Panel: London, UK, 2010.

22. Mayson, S. Civil Legal Aid: Squaring the (Vicious) Circle; Legal Services Institute; Available online: https:/ / stephenmayson.files. wordpress.com/2013/08/mayson-2010-legal-aid-squaring-the-vicious-circle.pdf (accessed on 1 March 2021).

23. Nelson, P. Information and Consumer Behavior. J. Polit. Econ. 1970, 78, 311-329. [CrossRef]

24. Nelson, P. Advertising as Information. J. Polit. Econ. 1974, 82, 729-754. [CrossRef]

25. Darby, M.R.; Karni, E. Free competition and the optimal amount of fraud. J. Law Econ. 1973, 16, 67-88. [CrossRef]

26. Semple, N. Legal Services Regulation at the Crossroads. Justitia's Legions; Edward Elgar Publishing: Cheltenham, UK; Northampton, MA, USA, 2015; ISBN 978-1-78471-165-8.

27. Love, J.H.; Stephen, F.H. Deregulation and Professional Boundaries: Evidence from the English Legal Profession. Bus. Econ. Hist. 1997, 26, 792-804.

28. Auriol, E.; Schilizzi, S.G.M. Quality Signaling through Certification. J. Dev. Econ. 2015, 116, 105-121. [CrossRef]

29. Akerlof, G.A. The Market for "Lemons": Quality Uncertainty and the Market Mechanism. Q. J. Econ. 1970, 84, 488-500. [CrossRef]

30. Thornton, R.J.; Timmons, E.J. The de-licensing of occupations in the United States. Mon. Labor Rev. 2015, 1-19. [CrossRef]

31. Białowolski, P. Concepts of Confidence in Tendency Survey Research: An Assessment with Multi-group Confirmatory Factor Analysis. Soc. Indic. Res. 2015, 123, 281-302. [CrossRef] [PubMed]

32. Brown, T.A. Confirmatory Factor Analysis for Applied Research; The Guilford Press: New York, NY, USA, 2006.

33. Bialowolski, P.; Weziak-Bialowolska, D. External factors affecting investment decisions of companies. Economics 2014, 8, 1-21. [CrossRef]

34. Schwarz, G. Estimating the Dimensions of a Model. Ann. Stat. 1978, 6, 461-464. [CrossRef]

35. Browne, M.W.; Cudeck, R. Alternative ways of assessing model fit. In Testing Structural Equation Models; Sage: Newsbury Park, CA, USA, 1993; pp. 136-162.

36. $\mathrm{Hu}, \mathrm{L} . ;$ Bentler, P.M. Cutoff criteria for fit indexes in covariance structure analysis: Conventional criteria versus new alternatives. Struct. Equ. Model. 1999, 6, 1-55. [CrossRef]

37. Rust, R.T.; Zahorik, A.J.; Keiningham, T.L. Service Marketing; HarperCollins: New York, NY, USA, 1996.

38. Białowolski, P.; Masior, M. Deregulation, quality and access-The case of legal professionals in Poland. Soc. Policy Adm. 2021. [CrossRef]

39. Matjasko, J.L.; Cawley, J.H.; Baker-Goering, M.M.; Yokum, D.V. Applying Behavioral Economics to Public Health Policy. Am. J. Prev. Med. 2016, 50, S13-S19. [CrossRef] [PubMed]

40. Pagliero, M. The impact of potential labor supply on licensing exam difficulty. Labour Econ. 2013, 25, 141-152. [CrossRef]

41. Koumenta, M.; Pagliero, M.; Rostam-Afschar, D.; Bialowolski, P.; Kleiner, M.; Masior, M.; Pagano, E.; Richiardi, L.; Strohmaier, K.; Williams, M. Effects of Regulation on Service Quality. Evidence from Six European Cases; Publication Office of the European Union: Luxembourg, 2018. [CrossRef] 